\title{
Philosophical and Pedagogical Problems with Constructivism in Science Education
}

\section{Michael R. Matthews}

\section{(2) OpenEdition \\ Journals}

Electronic version

URL: http://journals.openedition.org/trema/2823

DOI: $10.4000 /$ trema.2823

ISSN: 2107-0997

\section{Publisher}

Faculté d'Éducation de l'université de Montpellier

Printed version

Date of publication: 1 December 2012

Number of pages: 40-55

ISBN: 1167-315X

ISSN: 1167-315X

Electronic reference

Michael R. Matthews, « Philosophical and Pedagogical Problems with Constructivism in Science Education », Tréma [Online], 38 | 2012, Online since 01 December 2014, connection on 21 December 2020. URL : http://journals.openedition.org/trema/2823 ; DOI : https://doi.org/10.4000/trema.2823

This text was automatically generated on 21 December 2020.

Trema 


\title{
Philosophical and Pedagogical Problems with Constructivism in Science Education
}

\author{
Michael R. Matthews
}

Constructivism as a theory of knowledge, learning and instruction has been the major theoretical influence in contemporary science and mathematics education; and in its post-modernist and deconstructionist form, it is a significant influence in literary, artistic, history and religious education. Its impact is evident in theoretical debates, curriculum construction, and pedagogical practice in all of these subjects. It is of course not just a single unified theory but a broad scholarly programme of many philosophical and pedagogical hues, ${ }^{1}$ so it needs be understood that not all of the following commentary is applicable across the whole constructivist spectrum, nevertheless the criticisms are applicable in the identified cases that are dealt with and readers can judge for themselves the more general applicability of the anti-

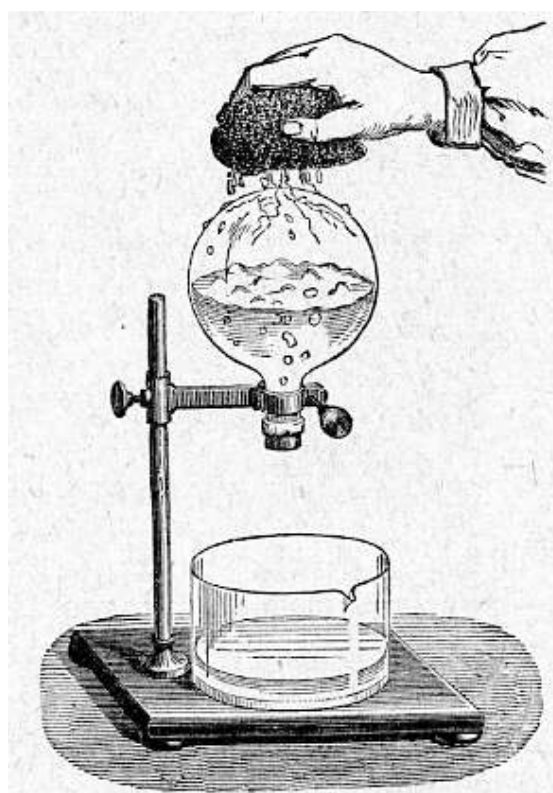

Fig. i4o. - Bouilleur de Franklin.

En versant de l'eau froide sur un ballon vide d'air et renfermant de l'eau chaude, on provoque une condensation partielle de la vapeur et, par suite, l'ébullition de leau chaude. 


\section{Some History: The Rising Tide of Constructivism}

2 Constructivism has been the rising tide in education that floated a range of childcentered, multicultural, feminist, and self-styled progressive and supposedly reformist programmes such as queerism (the view that there are uniquely homosexual understandings of knowledge and the world) in education. These programmes typically have philosophical and pedagogical dimensions, both of which rise with, and are supported by, constructivist theory. This is because constructivism typically presents itself both as a theory of learning (a psychological theory), a theory of knowledge (a philosophical, and specifically epistemological, theory) and even an ontological theory (frequently idealism, the world and its structures are as we create them).

3 So for example one can readily detect the formative and legitimating influence of constructivism in current Queer theory where two researchers claim that: «Using the lens of queer theory, we can view the hegemonic matrix, interrupt hetero-normative thinking, and broaden all students' potential for interpreting, representing, and perceiving experiences» (Snyder et Broadway, 2004, p. 621). They maintain that Queer theory « is both ontological and epistemological as it questions knowing and the nature of being ( (Snyder et Broadway, 2004, p. 619). And proceed to assert that «Truth of nature, then, becomes cultural interpretations of meaning» (Snyder et Broadway, 2004, p. 623). None of this strikes a discordant note to constructivist ears; indeed it is music to their ears, it is what constructivists predict and endorse - everybody moves to different educational and epistemological beats.

4 This is not the place for a detailed history of Constructivism but going back ten and twenty years, to the mid-1980s through to the late 1990s, there is no doubt that constructivism was a dominant influence in the theory, and to a lesser extent, the practice, of science and mathematics education; this period might be thought of as the high tide of constructivism. Countless science education conference presentations and plenary addresses, as well as numberless professional development workshops, were given over to articulating all of the many dimensions of Constructivism.

5 In a review article at the time, Peter Fensham claimed that « The most conspicuous psychological influence on curriculum thinking in science since 1980 has been the constructivist view of learning " (Fensham, 1992, p. 801). A former president of the US National Association for Research in Science Teaching (NARST) said at that time that: «A unification of thinking, research, curriculum development, and teacher education appears to now be occurring under the theme of constructivism [...] there is a lack of polarised debate » (Yeany, 1991, p. 1). Another past president of the same organisation wrote that «there is a paradigm war waging in education. Evidence of conflict is seen in nearly every facet of educational practice. [but] there is evidence of widespread acceptance of alternatives to objectivism, one of which is constructivism » (Tobin, 1993, p. ix).

6 A review of research in mathematics education noted that «In the second half of the 1980s public statements urging the introduction of radical constructivist ideas in school mathematics programs also began to assume bandwagon proportions" (Ellerton et Clements, 1991, p. 58). One authoritative bibliography at the time listed more than 1,100 studies informed by constructivist theoretical frameworks (Pfundt et Duit, 1991). There are even more in the 2009 version prepared by Duit and available on line <http:// 
omnis.if.ufrj.br/ marta/aprendizagememfisica/stcse-introduction.pdf>. He says of the bibliography that:

This research has been carried out within what is called the constructivist view including individual constructivist and social constructivist perspectives. The bibliography may therefore now be viewed as an attempt to document constructivist research in science education.

In the early 1990s an Editorial in The Journal of Teacher Education announced that:

Constructivism is the new rallying theme in education. Its popularity derives from its origins in a variety of disciplines, notably philosophy of science, psychology, and sociology. The implications of a constructivist perspective for education differ depending on its disciplinary foundation, but professional education groups as diverse as the National Association for the Education of Young Children and the National Council of Teachers of Mathematics have based revisions of their standards for practice on the constructivist assumption that learners do not passively absorb knowledge but rather construct it from their experiences (Ashton, 1992, p. 322).

8 Speaking of US science and mathematics education reforms at the time, Catherine Fosnot commented that « Most recent reforms advocated by national professional groups are based on constructivism. For example the National Council for Teachers of Mathematics [...] and [...] the National Science Teachers Association » (Fosnot, 1996, p. x).

Another observer supported Fosnot's account writing that:

As any glance at contemporary educational literature demonstrates, the concept of " constructivism » carries with it enormous appeal. Contemporary literature also reveals that many current educational reform initiatives encourage teaching practices that many people refer to as constructivist (Null, 2004, p. 80).

\section{Constructivist Impact on Research and Classrooms}

Constructivist theory has had an impact on education way beyond the confines of research journals and scholarly conferences that can be documented in ERIC searches; it has been adopted as the "official » pedagogical theory in a number of countries, states and provinces. These include at least the following: Ontario Province of Canada, Thailand, Greece, Turkey, New Zealand, India, Taiwan, Spain, the Australian state of Western Australia, and some states and school districts of the USA. Constructivism is ubiquitous in North American teacher education programmes.

10 As the Constructivist tide rose, it progressively occupied more and more educational, philosophical and cultural space. Although constructivism began with Piaget, Vygotsky and Bruner as a theory of learning and hence a moderately limited psychological theory it fairly quickly became a theory of teaching, a theory of education, a theory of the origin of ideas, and a theory of both personal knowledge and scientific knowledge. It became education's answer to physics' " Grand Unified Theory ».

11 The range of territories into which constructivism expanded as its tide rose can be seen in the subheadings of just one article: "A constructivist view of learning", " $\mathrm{A}$ constructivist view of teaching ", «A view of science », «Aims of science education », «A constructivist view of curriculum» and "A constructivist view of curriculum development » (Bell, 1991).

12 For some, constructivism is even larger than a theory of learning, education and science; it is a worldview or weltanschuung. Yvon Pépin, stated that constructivism: «also offers a 
global perspective on the meaning of the human adventure, on the way human beings impart meaning to their whole existence in order to survive and adapt " (Pépin, 1998, p. 174). Whilst another constructivist wrote:

To become a constructivist is to use constructivism as a referent for thoughts and actions. That is to say when thinking or acting, beliefs associated with constructivism assume a higher value than other beliefs. For a variety of reasons the process is not easy (Tobin, 1991, p. 1).

In Tobin's formulation, Constructivism becomes an ideology. In the above quotation " constructivism" can be replaced with "communism ", "Catholicism ", "Islam ", «Liberalism » and most other isms without any necessity to change the structure of the statement.

\section{Constructivist Entanglement of Psychology and Philosophy}

Constructivism is presented as both as a theory of learning (a psychological theory) and a theory of knowledge (a philosophical, and specifically epistemological, theory). It is selfconsciously a composite theory. A typical account of the theory is given by Catherine Fosnot in a much-cited constructivist anthology:

Constructivism is a theory about knowledge and learning; it describes both what «knowing» is and how one "comes to know». Based on work in psychology, philosophy, science and biology, the theory describes knowledge not as truths to be transmitted or discovered, but as emergent, developmental, non-objective, viable constructed explanations by humans engaged in meaning-making in cultural and social communities of discourse. Learning from this perspective is viewed as a selfregulatory process of struggling with the conflict between existing personal models of the world and discrepant new insights, constructing new representations and models of reality as a human meaning-making venture with culturally developed tools and symbols, and further negotiating such meaning through cooperative social activity, discourse, and debate in communities of practice.

Although constructivism is not a theory of teaching, it suggests taking a radically different approach to instruction from that used in most schools (Fosnot, 2005, p. ix).

15 This characterisation of constructivism as being a composite of learning theory (psychology) with theory of knowledge (philosophy) is apparent in the writing of the founders of educational constructivism - Piaget, Vygotsky and Bruner. Piaget called his own theory "Genetic Epistemology", and this philosophical concern is reflected in the title of one of his books - Psychology and Epistemology (Piaget, 1972). Jerome Bruner speaking of his famous Process of Education book (Bruner, 1960) that presented a constructivist alternative to didactic, transmissionist, behaviourist-informed pedagogy wrote that:

Its ideas sprang from epistemology and the sciences of knowing [...] all of us were, I think, responding to the same « epistemic » malaise, the doubts about the nature of knowing that had come first out of the revolution in physics and then been formalized and amplified by philosophy (Bruner, 1983, p. 186).

It is important to recognise a persistent ambiguity in the constructivist linking of learning theory to epistemology. The founders of constructivism regarded epistemology seriously as a philosophical endeavour; they offered accounts of what constitutes human knowledge and how knowledge claims were compared and tested. But subsequently many 
in the constructivist tradition simply collapse epistemology into psychology, and although they talk about studying the acquisition of knowledge, they really mean studying the acquisition of beliefs. One such example occurs in a recent book of Andreas Quale, Radical Constructivism (Quale, 2008). Quale says learning is the process through which we gain knowledge and knowledge is the product of the learning process (p. 45). He of course recognises, with Plato and the bulk of the philosophical and commonsensical tradition, that « it is possible to learn things that are not true » (p. 45); but this is not a bother to him because "such an association of knowledge with truth is not made in constructivism» (p. 45).

Indeed this is a problem that constructivists share with many cognitive psychologists for whom knowledge is merely "whatever can be retrieved from long-term memory ", and for whom « social knowledge exists in long-term memory ».

But merely saying that there is no problem in identifying learning with knowledge does not mean that there is no problem. In children's books a threat might go away because a person closes their eyes, but this comforting event seldom happens in the real world, or in the world of philosophical argument. Everyday, all around the world, people learn all sorts of silly and plainly false things regarding both the natural and social worlds. Think of widespread and entrenched superstitions and magical beliefs current in all cultures. Think of what children learn everyday about the solar system by just watching the sun go around the earth. Think of lessons in Taliban schools, in North Korean re-education camps, in fundamentalist school biology classes, in AIDS-denying South African communities, in Roman Catholic seminaries, and so on. Think of the millions of Chinese citizens who not so long ago were taught and assiduously learnt Chairman Mao thought; the millions of Soviet citizens who learnt Stalinist dialectics; and the millions of German citizens who learnt National-Socialist science. Pretty much all of what was learnt in these foregoing examples was simply wrong, but for many personal constructivists it is nevertheless knowledge simply in virtue of it being learnt, and for more demanding social constructivists, it is knowledge in virtue of the beliefs being widely shared and efficacious. And there is no doubt they are embedded in long-term memory: prizes and honours were bestowed on students for learning off by heart the « Thoughts of Chairman Mao ", whole chapters of the Koran or whole sections of the Roman Catholic Catechism.

Constructivists typically do not like or advocate such rote learning, but the problem, to repeat, is their breaking of the " association of knowledge with truth » as Quale explicitly does above. It truth goes, then there is a long queue of alternatives lined up to take its place: personal advancement, social cohesion, economic gain, religious conformity, national honour and so forth. In all of the foregoing cases, something has been learnt, indeed very well learnt, and for constructivists, if it has been learnt, it is knowledge; there is no other court of appeal, certainly not the court of nature or social reality.

\section{An Evidential Dilemma}

There is a clear « Evidential Dilemma » for constructivists who try to support their theory by empirical research. On the one hand they wish to appeal to the nature of cognitive realities (learning processes) and epistemological realities (especially the history of science) to support their pedagogical, curricular and epistemological proposals. Yet on the other hand they mostly say that such realities cannot be known, or are forever 
inaccessible to us. For many constructivists, reality collapses into the completely subjective « my experience of reality ${ }^{2}{ }^{2}$

Thus one researcher who champions "socio-transformative constructivism » (STC), and who supports the position with a study of 18 students in a secondary science methods class, is impelled to remark that:

Note that by using the term empirical evidence, I am not taking a realist or empiricist stance, nor any other Western orientation. I use the term «empirical evidence » with the understanding that knowledge is socially constructed and always partial. By «empirical evidence» I mean that information was systematically gathered and exposed to a variety of methodology checks. Hence in this study I do not pretend to capture the real world of the research participants (realism), nor do I pretend to capture their experiential world (empiricism). What I do attempt is to provide spaces where the participants' voices and subjectivities are represented along with my own voice and subjectivities (Rodriguez, 1998, p. 618).

One can get the general drift of this quotation, namely that there is no " uncontested " evidence, but instead of trying to get more adequate evidence, the author proposes that research should: "provide spaces where the participants " voices and subjectivities are represented along with my own voice and subjectivities. As a guide to educational research, this is completely opaque. Unfortunately such mystification has become the coin of the constructivist realm.

\section{Epistemological Skepticism}

All constructivists are epistemological relativists; it simply goes with the constructivist territory to deny that one account or theory can be better than another (with «better " inevitably placed in scare quotes by constructivists), and likewise to deny that one account might be more true than another. ${ }^{3}$ Although epistemological relativism has its problems, ${ }^{4}$ it is not the most serious epistemological problem for constructivism. The really serious problem is not relativism but skepticism.

Constructivists constantly assert the sceptical thesis that we have no direct access to reality, that reality remains forever hidden. Antonio Bettencourt, for example, puts the matter this way:

[...] constructivism, like idealism, maintains that we are cognitively isolated from the nature of reality. [...] Our knowledge is, at best, a mapping of transformations allowed by that reality (Bettencourt, 1993, p. 46). Leaving aside the problem of understanding what is meant by the second half of the claim, the first half - «cognitive isolation» - resonates throughout constructivist writing.

Cognitive isolation from the world is a fundamental tenet of Ernst von Glasersfeld's radical constructivism. It is affirmed in just about all of his publications, with one clear statement being:

To claim true knowledge of the world, you would have to be certain that the picture you compose on the basis of your perceptions and conceptions is in every respect a true representation of the world as it really is. But in order to be certain that it is a good match, you should be able to compare the representation to what it is supposed to represent. This, however you cannot do, because you cannot step out of your human ways of perceiving and conceiving (von Glasersfeld 1995, p. 26).

Paul Cobb has written that: 
Constructivism is a non-representationist model of knowing in which the mental representations that people construct are regarded as learning with no necessary correspondence with an objective and a priori scientific ontology (Cobb, 1994, p. 13).

Philip Kitcher calls this assertion the The Inaccessibility of Reality Argument, or IRA for short. He says of it that: «the IRA is a terrorist weapon which anti-realists employ with enormous confidence » (Kitcher, 2001, p. 156). It has of course been utilised by many in the philosophic tradition: the British Empiricists, Continental Idealists, Logical Positivists, and more recently Nelson Goodman, Hilary Putnam and Richard Rorty. So the constructivist recourse to IRA is not without honourable pedigree.

But there have also been equally honourable opponents of IRA in philosophy. ${ }^{5}$ The opposing, « common sense realism », view was nicely stated by Moritz Schlick, in 1935. Against Carnap and Neurath, his fellow positivists, he stated:

I have been accused of maintaining that statements can be compared with facts. I plead guilty. I have maintained this. But I protest against my punishment: I refuse to sit in the seat of the metaphysicians. I have often compared propositions to facts; so I had no reason to suppose that it couldn't be done. I found, for instance, in my Baedeker the statement: «this cathedral has two spires ». I was able to compare it with « reality » by looking at the cathedral, and this comparison convinced me that Baedeker's assertion was true (Schlick, 1935, p. 65-66).

Schlick's «tourist » argument of course applies at the next level down. Viruses, bacteria, molecules and a host of microscopic entities were once only postulated and were indeed inaccessible to scientists and everyone else, but with refined technology they become as visible to students in laboratories as were Schlick's cathedral spires to the tourist walking through town.

The IRA thesis is not as « uncontestable » as constructivists make it out to be; it has been contested and found severely wanting. ${ }^{6}$

\section{Ontological Idealism}

Constructivists frequently combine the foregoing skeptical epistemological position with an idealist ontological position. Constructivists often enough make an ontological nod towards realism by saying that there is an external world, but they frequently go on to say that this supposed reality is created by the knowing subject. This is classical idealism, but its constant restatement does not seem to worry constructivists. Ernst von Glasersfeld, the radical constructivist who has had an enormous influence on contemporary science education research, wrote:

I can no more walk through the desk in front of me than I can argue that black is white at one and the same time. What constrains me, however, is not quite the same thing in the two cases. That the desk constitutes an obstacle to my physical movement is due to the particular distinctions my sensor system enables me to make and to the particular way in which I have come to coordinate them. Indeed, if I now could walk through the desk, it would no longer fit the abstraction I have made in prior experience (von Glasersfeld, 1990, p. 24).

This sounds profound and deep, but the argument is flawed, and obviously so. For the realist, the inability of our body to " walk through » another body has nothing to do with our sensory powers, but everything to do with the composition and structures of the bodies. Changing our sensory powers will no more allow us to walk through a hitherto impenetrable table, than changing our shirt would allow us to. Upon dying we lose all 
sensory powers, but this does not mean our body can then penetrate a table; our having or not having sensory powers makes no difference to the penetrability of the table; to think that it does is just philosophical idealism.

John Staver, a very prominent constructivist, put the idealist position as follows:

[...] For constructivists, observations, objects, events, data, laws, and theory do not exist independently of observers. The lawful and certain nature of natural phenomena are properties of us, those who describe, not of nature, that is described (Staver, 1998, p. 503).

Again, this is a flawed position. Observations clearly depend upon us, but not the objects observed nor their structures. Philosophical alarm bells should ring when an author runs together « observations » with " events » and « objects ». For a realist, and for any serious scientist, there are categorical differences between these classes. Only a philosophical idealist can run them together without alarm bells ringing.

Rosalind Driver, another very famous and influential science educator, frequently affirmed the idealist position. For instance she wrote:

[...] science as public knowledge is not so much a "discovery " as a carefully checked «construction» [...] and that scientists construct theoretical entities (magnetic fields, genes, electron orbitals...) which in turn take on a «reality» (Driver, 1988, p. 137).

So the earth does not have a structure geophysicists impose it; there is not an evolutionary structure in the animal world till biologists impose such structure; atoms have no structure until such is imposed by physicists; and so on. If gravity waves are our creation, why spend so much time and money looking for them?

This idealist philosophical tradition has its critics. As with the IRA position, idealism has its problems, to put not too fine a point on it.

Despite Driver's basic argument form being fallacious, it is nevertheless wide-spread. The argument has the form:

Premise: Some concept is a human construction.

Conclusion: Therefore the reference of the concept does not exist.

One only has to state this argument to see that it is an invalid inference, and its validity depends upon making explicit a suppressed premise of the form:

Suppressed premise: All concepts that are human constructions can have no existential reference.

But this suppressed premise is simply dogma for which no evidence is provided. Not only are « electron orbitals» and «magnetic fields» human constructions, but so also are " my house », « mountain ", « table » and all the other observational terms we use. If the foregoing widespread constructivist argument, utilised by Rosalind Driver, were valid, then not only would electron orbitals not exist, neither would our house, the tables in it, or mountains that we might live near. Indeed, given that the personal pronoun « I » is a human construction, we might not exist ourselves! But such considerations are frequently dismissed as " philosophical quibbles ».

To conclude, philosophical mistakes of constructivists, mistakes that make it simply incompatible with the pursuit of both science and science learning are first its deeprooted epistemological scepticism and second its ontological idealism. Both these matters were raised and comprehensively argued some twenty years ago by the Australian 
philosopher Wallis Suchting who concluded a long and detailed analysis of Ernst von Glasersfeld's radical constructivism with the judgement that:

First, much of the doctrine known as « constructivism » [...] is simply unintelligible. Second, to the extent that it is intelligible [...] it is simply confused. Third, there is a complete absence of any argument for whatever positions can be made out. [...] In general, far from being what it is claimed to be, namely, the New Age in philosophy of science, an even slightly perceptive ear can detect the familiar voice of a really quite primitive, traditional subjectivistic empiricism with some overtones of diverse provenance like Piaget and Kuhn (Suchting, 1992, p. 247).

Disappointingly, this article has largely been ignored by educational constructivists.

\section{Problems with Constructivist Pedagogy}

Most constructivists see a connection between constructivist theory of learning and knowledge on the one hand and pedagogical advice for teachers on the other. This is why constructivism has become so widely adopted in teacher education programmes around the world. One response to criticism of constructivist theory is to say that although the theory might be poorly articulated and even be philosophically problematic, nevertheless constructivist pedagogy is valuable and should be supported (Grandy, 1997). This position is understandable, but it rests on a moot point: How efficacious is constructivist pedagogy in teaching science? A good deal of research says that it is not very effective at all.

Many science educators are interested in finding out how, on constructivist principles, somebody teaches a body of scientific knowledge that is in large part abstract (depending on notions such as velocity, acceleration, force, gene, vectors), that is removed from experience (propositions about atomic structure, cellular processes, astronomic events), that has no connection with prior conceptions (ideas of viruses, antibodies, molten core, evolution, electromagnetic radiation), and that is alien to common-sense, and in conflict with everyday experience, expectations and concepts? Teaching a body of knowledge involves not just teaching and explaining the concepts of science, but also the method, and something of the methodology or theory of method - how scientific claims are vindicated, proved or established; how alternative theories and hypotheses are appraised; how data relates to theory and vice versa. How all of this is to be taught, without teachers actually conveying something to pupils, is a moot point. Just as it is impossible for a person to learn to play chess without the rules of chess in some way being conveyed to him or her, so to with science; the rules and methodologies cannot just be made up by the individual. So the rule « it is true because I want it to be » is simply not an allowable rule and students need to be taught that.

Rosalind Driver and colleagues correctly maintain that:

[...] learning science involves being initiated into the culture of science. If learners are to be given access to the knowledge systems of science, the process of knowledge construction must go beyond personal empirical enquiry. Learners need to be given access not only to physical experiences but also to the concepts and models of conventional science (Scott et al., 1994, p. 6).

But having made the above claim they go on to say that:

The challenge for teachers lies in helping learners to construct these models for themselves, to appreciate their domains of applicability and, within such domains, to use them. 
One might reasonably ask whether, at this point, learning theory, or ideology, is simply getting in the way of good teaching. Why must learners construct for themselves the ideas of potential energy, mutation, linear inertia, photosynthesis, valency, and so on? Why not explain these ideas to students, and do it in such a way that they understand them? This process may or may not be didactic: it all depends on the classroom circumstance. There are many ways to explain science: didacticism is just one of them.

The supposed efficacy of constructivist, or minimally-guided, pedagogy has recently been challenged by educational researchers. Richard Mayer, a past-President of the Division of Educational Psychology of the American Psychological Association, a former editor of the Educational Psychologist and a former co-editor of Instructional Science, in something of a landmark study, reviewed an extensive body of research on constructivist pedagogy and concluded that it did not work, and where it did work, it worked in virtue of departing from constructivist principles (Mayer, 2004). His analysis was confirmed by Kirschner, Sweller and Clark who, in another review article, argued that:

[...] the past half century of research on this issue has provided overwhelming and unambiguous evidence that unguided or minimally guided learning is significantly less effective and efficient than guidance that is specifically designed to support the cognitive processing necessary for learning. Not only is minimally-guided learning ineffective for most learners, it may even be harmful for some [...]. The best evidence developed over the past half century supports the view that minimallyguided learning does not enhance student achievement any more than throwing a non-swimmer out of a boat in the middle of a deep lake supports learning to swim (Kirschner, Sweller et Clark, 2006, p. 75).

Such conclusions seem obvious, and dictated by the very nature of the discipline of science. Someone learning to play chess has to be told the rules by someone who knows the rules; learners cannot make up the rules, they cannot negotiate the rules, and even if they brainstorm to the conclusion that rooks can move diagonally, this does not mean that rooks can so move in a formal game of chess. Knowledge of what is allowed and not allowed in chess has to be transmitted; further competence in chess depends not just on knowing the rules, but on guidance and worked examples; so to in learning science.

\section{Conclusion: The Ebbing Tide}

8 Constructivism has done a service to science and mathematics education: by alerting teachers to the function of prior learning and extant concepts in the process of learning new material, by stressing the importance of understanding as a goal of science instruction, by fostering pupil engagement in lessons, and other such progressive matters. But liberal educationalists can rightly say that these are pedagogical commonplaces, the recognition of which goes back at least to Socrates. It is clear that the best of constructivist pedagogy can be had without constructivist epistemology Socrates, Montaigne, Locke, Mill, and Russell are just some who have conjoined engaging, constructivist-like, pedagogy with non-constructivist epistemology.

Constructivism has also done a service by making educators aware of the human dimension of science: its fallibility, its connection to culture and interests, the place of convention in scientific theory, the historicity of concepts, the complex procedures of theory appraisal, and much else. But again realist philosophers can rightly maintain that 
constructivism does not have a monopoly on these insights. They can be found in the work of thinkers as diverse as Mach, Duhem, Bachelard, Popper, and Polanyi.

However after sustained philosophical criticism, ${ }^{7}$ and more recently refutation of its claims to being a guide for successful pedagogy, ${ }^{8}$ there are some signs that constructivist influence is waning and that more realistic, limited and better grounded philosophical and instructional claims are taking its place. Indeed one very prominent constructivist and editor of constructivist anthologies has published an article titled « Constructivism in Education: Moving On » (Tobin, 2000). In this he writes:

The critical mass of science educators are still making sense of their praxis in terms of constructivism, but in a short time we will be in another theoretical epoch. [...] As an axiom, however, constructivism is the ether for an expanding constellation of theories that illuminate my praxis in science education (p. 250-251).

Most physicists have given up on the ether as a serious explanatory entity, this article will argue that educators, Tobin's advice not withstanding, should do the same with constructivism.

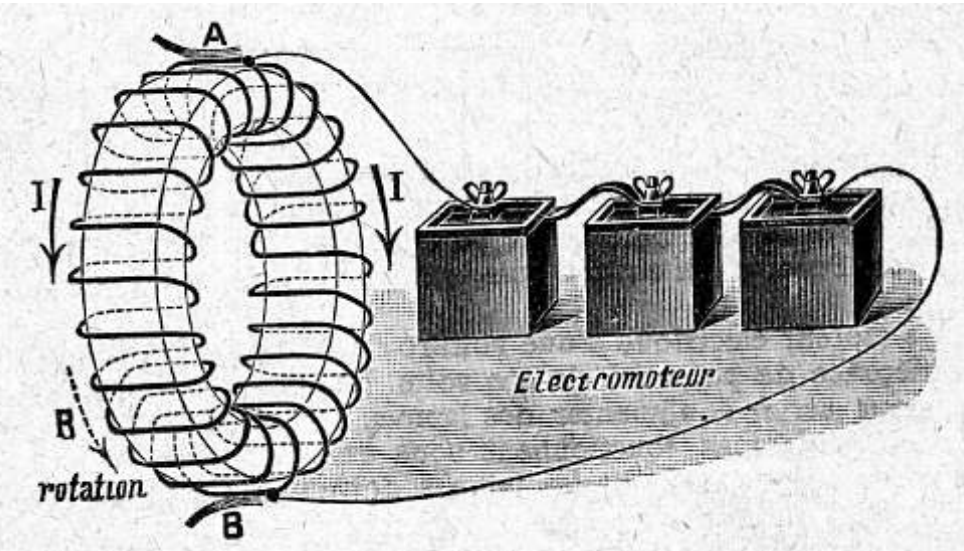

Fig. 98. - Marche des courants dans le moteur.

Les deux moitiés de l'anneau sont parcourues par des courants inverses et reçoivent du champ exterieur des actions concordantes.

Physique, troisième année (enseignement primaire supérieur), ouvrage rédigé conformément aux programmes officiels du 26 juillet 1909 et orné de 152 gravures. Chassagny, M., Carré, F., deuxième édition. Hachette : Paris, 1918. Source : CEDRHE, 22941, p. 171.

\section{BIBLIOGRAPHY}

Ashton, P.T., Editorial, Journal of Teacher Education, 43 (5), 1992, p. 322.

Bell, B.F. A Constructivist View of Learning and the Draft Forms 1-5 Science Syllabus, SAME Papers , 1991, p. 154-180.

Bettencourt, A., The Construction of Knowledge: A Radical Constructivist View. In K. Tobin (ed.), The Practice of Constructivism in Science Education. Washington (DC): AAAS Press. 1993, p. 39-50. 
Bickhard, M.H., Constructivism and Relativisms: A Shopper's Guide), Science and Education, 6 (1-2), 1997, p. 29-42.

Bruner, J.S., In Search of Mind: Essays in Autobiography. New York: Harper and Row. 1983.

Bruner, J.S. Process of Education. Random House, New York. 1960.

Cobb, P., Where is the Mind? Constructivist and Sociocultural Perspectives on Mathematical Development, Educational Researcher, 23 (7), 1994, p. 13-20.

Driver, R., A Constructivist Approach to Curriculum Development. In P. Fensham (ed.), Development and Dilemmas in Science Education. New York: Falmer Press. 1988, p. 133-149.

Ellerton, N. and Clements, M.A., Mathematics in Language: A Review of Language Factors in Mathematics Learning. Geelong (Victoria): Deakin University Press. 1991.

Fensham, P.J., Science and Technology. In P. W. Jackson (ed.), Handbook of Research on Curriculum. New York: Macmillan. 1992, p. 789-829.

Fosnot, C.T. (ed.) Constructivism: Theory, Perspectives, and Practice, 2nd Edition. New York: Teachers College Press. 2005.

Fosnot, C.T., Constructivism: A Psychological Theory of Learning. In C.T. Fosnot (ed.), Constructivism: Theory, Perspectives, and Practice. New York: Teachers College Press. 1996, p. 8-33.

Good, R., Wandersee, J. and St. Julien, J., Cautionary Notes on the Appeal of the New "Ism" (Constructivism) in Science Education. In K. Tobin (ed.), Constructivism in Science and Mathematics Education. Washington (DC): AAAS. 1993, p. 71-90.

Grandy, R. E., Constructivism and Objectivity: Disentangling Metaphysics from Pedagogy, Science and Education, 6 (1-2), 1997, p. 43-53. Reprinted in M. R. Matthews (ed.), Constructivism in Science Education: A Philosophical Examination. Dordrecht: Kluwer Academic Publishers, 1998, p. 113-123.

Kirschner, P., Sweller, J. and Clark, R. E., Why Minimally Guided Learning Does Not Work: An Analysis of the Failure of Discovery Learning, Problem-Based Learning, Experiential Learning and Inquiry-Based Learning, Educational Psychologist, 41 (2), 2006, p. 75-96.

Kitcher, P., Real Realism: The Galilean Strategy, The Philosophical Review, 110 (2), 2001, p. 151-97.

Klahr, D. and Nigam, M., The equivalence of learning paths in early science instruction: Effects of direct instruction and discovery learning, Psychological Science, 15, 2004, p. 661-667.

Kragh, H., Social Constructivism, the Gospel of Science and the Teaching of Physics, Science and Education, 7 (3), 1998, p. 231-243. Reprinted in M.R. Matthews (ed.), Constructivism in Science Education: A Philosophical Examination. Dordrecht: Kluwer Academic Publishers, 1998. p. 125-137.

Matthews, M. R., Old wine in New Bottles: A Problem with Constructivist Epistemology. In H.A Alexander (ed.), Philosophy of Education 1992, Urbana (IL.): US Philosophy of Education Society. 1992, p. 303-311.

Mayer, R. E., Should there be a Three-Strikes Rule Against Pure Discovery Learning? The Case for Guided Methods of Instruction, American Psychologist, 59 (1), 2004, p. 14-19.

McCarty, L. P. and Schwandt, T. A., Seductive Illusions: Von Glasersfeld and Gergen on Epistemology and Education. In D. C. Phillips (ed.) Constructivism in Education: 99th Yearbook of the National Society for the Study of Education. Chicago: NSSE. 2000, p. 41-85.

Niiniluoto, I. (1). Realism, Relativism and Constructivism, Synthese, 89 (1), 1991, p. 35-162.

Nola, R. (ed.). Relativism and Realism in Science. Dordrecht: Reidel Academic Publishers. 1988. 
Nola, R., Constructivism in Science and in Science Education: A Philosophical Critique, Science and Education, 6 (1-2), 1997, p. 55-83. Reprinted in M. R. Matthews (ed.), Constructivism in Science Education: A Philosophical Examination. Dordrecht: Kluwer Academic Publishers, 1998, p. 31-59.

Nola, R., « Naked Before Reality; Skinless Before the Absolute »: A Critique of the Inaccessibility of Reality Argument in Constructivism, Science and Education, 12 (2), 2003, p. 131-166.

Norris, C., Against Relativism: Philosophy of Science, Deconstruction and Critical Theory. Oxford: Blackwell. 1997.

Null, J.W., Is Constructivism Traditional? Historical and Practical Perspectives on a Popular Advocacy, The Educational Forum, 68 (2), 2004, p. 180-188.

Papayannakos, D. P., Philosophical Skepticism not Relativism is the Problem with the Strong Programme in Science Studies and with Educational Constructivism, Science and Education, 17 (6), 2008, p. 573-611.

Pépin, Y., Practical Knowledge and School Knowledge: A Constructivist Representation of Education. In M. Larochelle, N. Bednarz and J. Garrision (eds.), Constructivism and Education. Cambridge: Cambridge University Press. 1998, p. 173-192.

Pfundt, H. and Duit, R., Bibliography of Students' Alternative Frameworks and Science Education, 3rd Edit. Institute for Science Education, University of Kiel. 1991.

Phillips, D. C., Coming to Terms with Radical Social Constructivisms, Science and Education, 6 (1-2), 1997, p. 85-104. Reprinted in M. R. Matthews (ed.), Constructivism in Science Education: A Philosophical Examination. Dordrecht: Kluwer Academic Publishers, 1998, p. 139-158.

Piaget, J., Psychology and Epistemology: Towards a Theory of Knowledge. Harmondsworth: Penguin. 1972.

Quale, A., Radical Constructivism. A Relativist Epistemic Approach to Science Education. Rotterdam: Sense Publishers. 2008.

Rodriguez, A. J., Strategies for Counterresistance: Toward Sociotransformative Constructivism and Learning to Teach Science for Diversity and for Understanding, Journal of Research in Science Teaching, 35 (6), 1998, p. 589-622.

Schlick, M., Facts and Propositions, Analysis, 2 (5), 1935, p. 65-70.

Scott, P., Asoko, H., Driver, R. and Emberton, J., Working from Children's Ideas: Planning and Teaching a Chemistry Topic from a Constructivist Perspective. In P. Fensham, R. Gunstone and R. White (eds.), The Content of Science: A Constructivist Approach to its Teaching and Learning. London: Falmer Press. 1994, p. 201-220.

Siegel, H., Relativism Refuted. Dordrecht: Reidel. 1987.

Slezak, P., A Critique of Radical Social Constructivism. In D. C. Phillips (ed.), Constructivism in Education: 99th Yearbook of the National Society for the Study of Education. Chicago: NSSE. 2000, pp. 91-126.

Small, R., A Fallacy in Constructivist Epistemology, Journal of Philosophy of Education, 37 (3), 2003, p. 483-502.

Snyder, V. L. and Broadway, F. S., Queering High School Biology Textbooks, Journal of Research in Science Teaching, 41 (6), 2004, p. 617-636.

Staver, J., Constructivism: Sound Theory for Explicating the Practice of Science and Science Teaching, Journal of Research in Science Teaching, 35 (5), 1998, p. 501-520. 
Suchting, W. A., Constructivism Deconstructed, Science and Education, 1 (3), 1992, p. 223-254.

Tobias, S. and Dufffy, T. (eds.). Constructivism Theory Applied to Instruction: Success or Failure? Hillsdale (NJ): Lawrence Erlbaum. 2009.

Tobin, K. (ed.). The Practice of Constructivism in Science and Mathematics Education. Washington (DC): AAAS Press. 1993.

Tobin, K., Constructivist Perspectives on Research in Science Education, paper presented at the annual meeting of the National Association for Research in Science Teaching, Lake Geneva, Wisconsin. 1991.

Tobin, K., Constructivism in Science Education: Moving On. In D.C. Phillips (ed.), Constructivism in Education. Chicago: National Society for the Study of Education. 2000, p. 227-253.

Tuovinen, J. E., and Sweller, J., A comparison of cognitive load associated with discovery learning and worked examples, Journal of Educational Psychology, 91, 1999, p. 334-341.

Von Glasersfeld, E., An Exposition of Constructivism: Why Some Like It Hot. In Davis, R., Maher, C. and Noddings, N. (eds.), Constructivist Views on the Teaching and Learning of Mathematics. Reston (VA.): National Council of Teachers of Mathematics. 1990, p. 19-30.

Von Glasersfeld, E., Radical Constructivism: A Way of Knowing and Learning. London: Falmer Press. 1995.

Yeany, R.H., A Unifying Theme in Science Education? NARST News, 33 (2), 1991, p. 1-3.

\section{NOTES}

1. In 1993 there were 21 differently named variants of constructivism (Good, Wandersee et St. Julien, 1993); twenty years later there are probably as many varieties as there are of Heinz beans. 2. On the relationship between constructivism and classic empiricism, see Matthews (1992) and Suchting (1992).

3. See Bickhard (1997) and Niiniluoto (1991).

4. See for instance Siegel (1987), Nola (1988) and Norris (1997).

5. See especially Nola (2003).

6. One extended and excellent treatment of this subject is Papayannakos (2008).

7. See especially the detailed papers of Suchting (1992), Slezak (2000), Nola (1997, 2003), Phillips (1997), Kragh (1998), McCarty et Schwandt (2000) and Small (2003).

8. See especially Mayer (2004), Klahr et Nigam (2004), Kirschner, Sweller et Clark (2006), Tuovinen et Sweller (1999), and contributions to Tobias et Duffy (2009).

\section{ABSTRACTS}

The paper will make two claims: first, that many constructivists embrace erroneous philosophical positions that are antithetical to the conduct of good science; and second, that Constructivism as a theory of learning promotes ineffective pedagogy and poor student learning. The philosophical errors identified are those associated with skepticism in epistemology and 
idealism in ontology. The pedagogical problem results from constructivism ignoring or minimising the basic point that learning is dependent upon guidance and instruction, the more so in a discipline such as physics. The paper will make some suggestions about why this unfortunate state of affairs has come to pass in science education research.

Cet article avance deux idées: premièrement, de nombreux constructivistes adoptent des positions philosophiques erronées qui sont antithétiques avec la conduite d'une bonne science; deuxièmement, le constructivisme comme une théorie de l'apprentissage promeut une pédagogie inefficace et un apprentissage pauvre pour les élèves. Les erreurs philosophiques identifiées sont celles associées au scepticisme en épistémologie et à l'idéalisme dans le domaine de l'ontologie. Le problème pédagogique provient du fait que le constructivisme ignore ou minimise le point fondamental selon lequel l'apprentissage dépend de l'accompagnement et de l'enseignement, et ce, à plus forte raison pour une discipline comme la physique. Cet article propose plusieurs explications de cet état insatisfaisant dans lequel s'est retrouvée la recherche en didactique des sciences.

\section{INDEX}

Mots-clés: constructivisme, idéalisme, ontologie, réalisme

Keywords: constructivism, idealism, ontology, realism

\section{AUTHOR}

\section{MICHAEL R. MATTHEWS}

School of Education, UNSW, Sydney 2052, Australia 